\title{
Return The "Sunk Costs Are Sunk" Concept To Principles Of Economics Textbooks
}

William Young Davis, (Email: wydavis@email.uncc.edu), University of North Carolina, Charlotte

\section{INTRODUCTION}

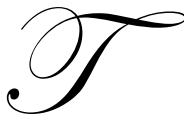

he "sunk costs are sunk" concept derives from the basic microeconomic principle of marginal analysis that decisions should be determined on the basis of marginal revenue and/or benefits versus marginal costs. Since marginal costs are those directly associated with an action, previous costs are not directly relevant to a current decision. This concept was not uncommon in principles of economics texts decades ago, but is found in very few current principles texts. ${ }^{1}$ Failure to understand the concept engenders a "mindset" that sunk costs are not sunk; the results are illogical and irrational decisions.

The purpose of this paper is to establish a compelling case for the inclusion of the profoundly important "sunk costs are sunk" concept in all principles of economics textbooks. First, the paper will provide examples of the concept's relevance in political/military decisions. Second, it will supply business examples of where failure to recognize this concept has led to nearly disastrous results. Third, it will provide numerous examples of faulty decisions by individuals resulting from the non-application of the concept. Finally, the paper will provide a psychological explanation for the common failure to properly incorporate the concept into logical and rational decision-making.

\section{POLITICAL/MILITARY FAILURES RESULTING FROM THE NON-APPLICATION OF THE "SUNK COSTS ARE SUNK" CONCEPT}

Given that the roots of modern economics are found in the political economy of the eighteenth and nineteenth centuries, and the recent trend reuniting economics and political science, the failure to apply this concept to political/military decisions and the resulting mistakes are relevant. While the following examples are a small sample, it will become evident why the non-application of this simple concept is so important.

Following the disastrous carnage of the First World War, the French Government constructed a defensive fortification between France and Germany that would presumably preclude any future German invasions. Named after the French General Andre Maginot, the Maginot Line was constructed over 87 miles separating France and Germany at a cost of over $\$ 2$ billion dollars (current dollars). The fortification included concrete bunkers; fortified artillery emplacements; underground dormitories, hospitals, and kitchens.

When Germany threatened France in 1939, the French were confident that their Maginot Line would easily repel any German invasion. The "mind set" of the French generals held that the enormously expensive Line would protect France. The French generals held to this mindset, even though they were aware that a flanking movement around the Line could occur through the Ardennes Forest. No preparations were made for the German flanking maneuver that occurred. The French were easily defeated because they failed to realize that the Maginot Line was a sunk cost.

\footnotetext{
${ }^{1}$ Two current texts that include the concept are Economics: Principles, Problems, and Policies by Campbell R. McConnell and Stanley L. Brue, sixteenth edition; and Economics: Private \& Public Choice by James D. Gwartnety, Richard L. Stroup, Russell S. Sobel, and David A Macpherson, tenth edition.
} 
As detailed in her book, The March of Folly, From Troy to Vietnam, Barbara W. Tuchman provides example after example of tragic political and military decisions that failed to recognize that "sunk costs are sunk." She labels the refusal to ignore sunk costs as wooden-headedness. "It consists in assessing a situation in terms of preconceived fixed notions while ignoring or rejecting any contrary signs." ${ }^{2}$ Millions and millions of men and women have been killed and seriously wounded because of these failures. She outlines in great detail the disastrous consequences of the decision to engage in a war in Vietnam, and even more irrationally to continue in a military campaign long after it was clearly apparent that victory could not be achieved. Very intelligent leaders refused for years to accept the fact that the Vietnam War was a sunk cost.

A more recent example is the 2003 Iraq war. When criticized for not adequately preparing for the aftermath of the war, the Pentagon responded that very little preparation was made, because a major preparation in itself would force the U.S. to go to war. According to a spokesman for the Pentagon, there was no "...planning for the aftermath of a war in Iraq out of concern that such planning would precipitate war...." ${ }^{\text {"3 }}$ In other words, once a plan for the aftermath of the war was developed, it would have to be employed-it could not be simply discarded as a sunk cost.

\section{AMERICAN BUSINESS MISTAKES RESULTING FROM IGNORING THE SUNK COST IS SUNK CONCEPT}

According to Business Week, May 4, 1998, Motorola dominated the cell phone market in 1994, selling 60 percent of all cell phones in the U.S. However, the company made the critical decision to ignore digital technology, and insisted that analog communication, in which it has excelled in the past, was the wave of the future. Despite continuing and almost desperate demands from wireless providers for digital cell phones, Motorola steadfastly refused to even consider switching from analog to digital cell phones. This mindset is epitomized by a statement by its former chief engineer who rejected the fact that analog technology was a sunk cost. He saw no need for digital phones because "Forty-three million analog customers can't be wrong." Motorola completely lost its dominance in the cell phone market, its share of the market falling from 60 percent in 1994 to 13 percent in 1997. It is still struggling to regain market share.

In 1937 McDonald's opened in California selling hotdogs. Adapting to the changing tastes of the American consumer, it became the largest fast-food chain. Its success continued as it switched its emphasis to hamburgers and to chicken McNuggets. However, by the 1990's, its success waned. According to Business Week, March 9, 1998, the value of its stock between 1996 and 1998 grew by only three percent while the Standard and Poor's 500-stock index grew by 63 percent. Its chief executive in 1997 held the mindset that McDonald's policy was to continue past policies, even if they were failing: "Do we have to change? No, we don't have to change. We have the most successful brand in the world." McDonald's was criticized by Davis Selected Advisers which stated that it needed a major managerial attitude change: "It means not holding the past sacred. There needs to be a sense of urgency." The seriousness of the problem was highlighted in a survey reported by Restaurants \& Institutions magazine that McDonald's food was rated by 2,800 consumers 87 th out of 91 -just behind Hooters. Only in 2003 did changes begin to take place when a former CEO was recalled to shift McDonald's attitude toward the future and away from the past.

According to Business Week, July 27, 1998, General Motors was suffering from a mindset problem in the 1990 's. GM's market share which had been near 50 percent three decades earlier had fallen to 28.6 percent in February 1998. Business Week attributed GM's continuing loss of market share to its mindset toward the past.

Despite all their progress in the past few years, the top brass-and the tens of thousands of apparatchiks who drone away in GM offices-are stuck in a time warp. They still approach the market with the hauteur and complacency-and gargantuan bureaucracy-that the company developed at mid-century, when it was the most dynamic industrial empire in the world.

An earlier example was Westinghouse Corporation in the early 1990's. According to Business Week, December 7, 1992, the CEO of Westinghouse established Westinghouse Credit in the late 1980's to compete with GE

\footnotetext{
${ }^{2}$ Barbara W. Tuchman, The March of Folly: From Troy to Vietnam (New York: Ballantine Books) 1984, Page 7.

${ }^{3}$ U.S.A. Today, November 6, 2003, Page 12A.
} 
Credit. To rapidly gain market share, very risky loans were made at even 110 percent of value. The result was a major failure by Westinghouse Credit. Instead of recognizing that "sunk costs are sunk", its CEO persisted with a mindset that somehow he would turn Westinghouse Credit around. After exhausting the capital of the parent corporation, the CEO borrowed from banks until they refused additional loans. He came perilously close to bankrupting Westinghouse. After he was terminated, Westinghouse Credit was sold for pennies on the dollar of investment costs.

\section{THE BEHAVIOR OF INDIVIDUALS}

The illogical mindset of politicians, military leaders, and business leaders extends to individuals in everyday decisions. How many of us have continued to consume the food on our plates beyond the point of needed nutrition, to the point where the marginal utility of an additional bite is zero or negative? Have we done this because the food is sitting there, and after all, it will be paid for, whether or not it is eaten? How many investors have watched the value of a stock fall, and then refuse to sell it until it returns to its purchase price? How many individuals have viewed a sporting event on TV long after the marginal cost exceeded the marginal benefit, just because they have already invested several hours viewing the event? How many college students choose the wrong major and yet remain in that major because they have already invested a semester or so in the wrong major? ${ }^{4}$ How many people remain in a relationship with the wrong partner because of the amount of time already spent in the relationship? Over time they slowly grow to view the relationship as some sort of investment worth saving, even if it is the wrong investment to begin with!

\section{A PSYCHOLOGICAL EXPLANATION OF WHY SUNK COSTS ARE NOT SUNK}

Given the widespread propensity for people to ignore this important concept, why is the mindset that sunk costs are not sunk so common? One possible explanation concerns parents and grandparents. It is typical behavior for parents to teach their kids not to ignore sunk costs. While the advice is obviously well-meaning, its impact can lead to serious mistakes. Below is list of these well-meaning, but misleading instructions to kids:

- $\quad$ Finish what you start!

- $\quad$ Any job worth doing is worth doing well!

- $\quad$ You made your bed, now lie in it!

- $\quad$ Don't be a quitter!

And if parents fail to indoctrinate their kids to not ignore sunk costs, friends who were also indoctrinated to not ignore sunk costs reinforce the bad advice. The common clichés that follow are in many cases exactly the wrong advice:

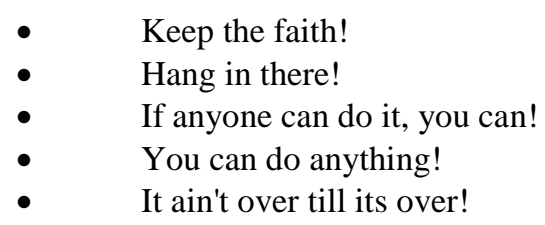

\section{SUMMARY AND CONCLUSIONS}

This paper has argued that the microeconomic concept of "sunk costs are sunk" should be included in all economic principles textbooks, to refute the common mindset that sunk costs are not sunk. First, the paper provided several political/military examples of decisions that ended in disaster because leaders operated with the wrong mindset. These included the decisions of the French after World War I, the long-term involvement of the U.S. in the

\footnotetext{
${ }^{4}$ A study at the University of North Carolina at Greensboro several years ago found that students who changed majors three times, and graduated in their fourth major, had higher graduation rates than students with one, two, or three different majors. The willingness of these successful students to change majors until they discovered the right one is a tribute to their understanding that sunk costs are sunk.
} 
Vietnam War, and of the lack of postwar planning by the U.S. prior to the 2003 Iraq War. In all three cases, a different mindset would have avoided the ensuing tragic results.

Secondly, the paper explored faulty business decisions that, in at least one instance, threatened the very existence of the company. In each example, the CEO held a mindset that the continuation of past policies would guarantee the corporation future success. In each example, the CEO was wrong. From Motorola to McDonalds to General Motors to Westinghouse, the company's future was jeopardized by a mindset that sunk costs are not sunk.

Thirdly, it addressed the common behavior of individuals based on the mindset that the past should rule the future. From decisions regarding how much to eat, when to sell a losing stock, when to turn off a sports broadcast, whether to change college major, or continue in a relationship, we often mistakenly, and sometimes with very negative consequences, make the wrong decisions.

Finally, the paper provided a psychological explanation that places blame for the wrong mindset at the feet of parents, and their parents, who taught their children that sunk costs are not sunk. Finish what you start, don't be a quitter. Friends, similarly indoctrinated, contribute to the wrong mindset. Hang in there, you can do it.

In conclusion, this paper calls for the return of the sunk costs are sunk concept to economics principles textbooks. The concept is profoundly important. As an added bonus, the inclusion of this concept provides an excellent opportunity for economists to demonstrate the relevance of economics to the "real world," whatever that is!

Paper presented at the International Business \& Economics Research and Teaching Conference, Las Vegas, Nevada, October 4-8, 2004. William Young Davis is a Professor of Economics at the University of North Carolina at Charlotte. 